\title{
The Link between Higher Order Thinking Skills, Representation and Concepts in Enhancing TIMSS Tasks
}

\author{
Nor'ain Mohd. Tajudin \\ Assoc. Prof., Sultan Idris Education University, Malaysia, norain@fsmt.upsi.edu.my
}

\section{Mohan Chinnappan}

Prof., University of South Australia, Adelaide, Australia,

mohan.chinnappan@unisa.edu.au

Students' performances in TIMSS have featured strongly in recent discussions and debates about the quality of mathematical learning outcomes both from teachers and policy makers. Findings of TIMSS trends showed that most high school students in Malaysia continue to perform at less than satisfactory levels, particularly, in tasks that are cognitively demanding. In this article, we present a critical analysis of selected TIMSS Tasks and demonstrate how to support students better in the use of Higher Order Thinking Skills (HOTS) in making progress with such tasks. In so doing we present analyses of TIMSS tasks and a model of these tasks that relate HOTS, representation and concepts which can be utilised by teachers to understand the role of HOTS better in empowering students shift to higher levels of cognitive funtioning in the context of tackling TIMSS and similarly demanding tasks. Our analyses and model provide an important starting point for the design of future professional development programs for Malaysian mathematics teachers in reconceptualising HOTS and implementing them in regular classrooms.

Key Words: thinking skills, problem solving, mathematics, TIMSS Tasks, teacher, level of cognition, representation

\section{INTRODUCTION}

Students' mathematics achievement is often associated with the future economic power and competitiveness of a country. Therefore, the desire to understand and identify factors that may have meaningful and consistent relationships with mathematics achievement has been shared among national policy makers and educators around the world. Today, it is widely accepted that the main purpose of educational systems is to teach students how to apply mathematics in a range of contexts. Higher Order Thinking Skills $[H O T S]$, such as logical thinking, critical thinking and reasoning skills are the basic skills for daily life, apart from the academic achievements in the schools (Marshall \& Horton, 2011). In order to increase the performance of students, the nature and 
development of these skills, specifically in the context of mathematics teaching and learning must be understood by teachers in all sectors of education (Santos-Trigo \& Moreno-Armella, 2013).

The extent to which mathematics teachers understand the role of HOTS in learning and applying mathematics is emerging to be an issue. Hinde and Perry (2007) commented that teacher in general tended to associate cognitive skills with the school's curriculum, with limited attention to the role of these skills in facilitating students' thinking and learning within particular subject. Further, teachers have limited opportunities to engage in activities with the students that will support the development of high order cognitive abilities (Ewing, Foster \& Whittington, 2011). The ability to integrate HOTS in mathematics can be hampered by a number of factors including teacher's limited knowledge of HOTS (Brookhart, 2010; Collins, 2014; Harpster, 1999).

Trends in International Mathematics and Science Study [TIMSS] and Programme of International Student Assessment [PISA] are two large-scale international comparative achievement studies that assess students' performances in mathematics. The pattern of results in TIMSS and PISA has revealed a marked decline in Malaysian lower secondary school students' mathematics performance (Ministry of Education [MOE], 2013). In the analyses of Malaysian students' performance in TIMSS over a number of years, Mullis, Martin, Foy and Arora (2012) found that only 2-10\% of the students are capable of interpreting the information and drawing generalization in solving complex problems. These activities collectively demand higher order thinking. Mullis et al. (2012) also showed that $60 \%$ of Malaysian students achieved below the average score set for international benchmarking. Collectively, these results suggest that Malaysian students understand the basic mathematical concepts but, in general, are not able to transfer that knowledge to the solution of non-routine problem situations similar to those that appear in TIMSS assessment (MOE, 2013).

Likewise, the results of another international study, PISA 2009 showed that Malaysian students' performances were located in the bottom of one third of all the 74 participating countries (MOE, 2013; Walker, 2011). As in the TIMSS study results, PISA's report for mathematics achievement showed that only a small proportion (8\%) of Malaysian students exhibited advanced levels of thinking. Thus, trends both in TIMSS and PISA provide evidence of Malaysian students' continuing difficulty in solving mathematical tasks which involve interpretation and synthesis, key aspects of HOTS.

It is critical that there is a need for future actions aimed at lifting Malaysian students' TIMSS and PISA performances. In a more recent policy decision, in an effort to enhance students' performances in mathematics, the Malaysian MOE (2013) had advocated for the integration of HOTS in mathematics and science. Our argument is that in order for HOTS to have a significant impact on students' engagement with mathematics and improve students' performance, researchers ought to undertake a finegrained analysis of tasks that students encounter in international tests such as TIMSS, and demonstrate how to support students in the use of HOTS in making progress in such tests. This exercise can also be expected to help teachers understand the nature and role of HOTS better in their teaching and learning in scaffolding deeper learning. 


\section{HOTS in Malaysian Context}

The Malaysian Integrated Curriculum for Secondary School Mathematics (Grade 8 to 12) aims to develop students to acquire mathematical knowledge, develop problem solving and decision making skills to cope with daily life challenges (MOE, 2011). Besides these, the curriculum also emphasise other elements that have to be taken into account and infused in the teaching and learning processes in the classroom namely mathematics reasoning skills. Students at all levels have to be trained to investigate their predictions or guesses by using concrete material, calculators, computers, mathematical representation and others. Logical reasoning has to be absorbed in the teaching of mathematics so that students can recognise, construct and evaluate predictions and mathematical arguments.

Based on the Malaysian curriculum, classroom practices placed emphasis on the understanding of concepts and the mastery of skills in three areas, namely, Number, Shapes and Space, and Algebra. The range of process skills including problem solving are embedded in each of these strands. As such, teachers are required to focus on the development of problem solving skills that involves four key steps: interpreting the problem, planning the strategy, carrying out the strategy, and reflecting on the solution obtained. Teachers are also recommended to give more space to the development of logical, systematic and creative thinking skills to produce an individual who is able to think logically, rationally and independently.

In broad terms, the above set of skills comes under the purview of HOTS. The Malaysian mathematics curriculum standard has used Bloom's taxonomy in referring to HOTS (Curriculum Development Centre [CDC], 2013). According to CDC (2013), Applying, Analyzing, Evaluating and Creating are considered as HOTS - these four processes were revised from Bloom's Taxonomy (Anderson \& Krathwohl, 2001). This conceptualizing of HOTS is consistent with our own analysis of HOTS.

The Ministry of Education has placed high emphasised on HOTS and classroom teachers are supported through a number of professional development programmes to integrate HOTS into their practices. However, it would seem that on the basis of continuing lower level of performance in TIMSS, there appear to be a disconnection between students' use of HOTS and the related problem solving attempts. Furthermore, research findings by Akademi Kepimpinan Pengajian Tinggi [AKEPT] indicate 50\% of the teachers were observed to not only failed to delivering their lessons effectively but also showed inability to inculcate HOTS (MOE, 2013).

\section{METHOD}

A major concern of this paper is to elucidate the role of HOTS in helping students tackle cognitively demanding problems in international assessment of mathematics such as TIMSS. For this purpose, we have identified two key dimensions of these context problems. Firstly, we have analysed Content that is embedded in the problems. Secondly, the construction of potentially useful Representations of the problems was identified. Figure 1 provides a schematic representation of these key constructs. As indicated in the figure, all three constructs inform are informed by each other. A 
problem was presented to show the links between HOTS, Content and Representation. Students needed to convert the problem into a visual representation to solve the problem. Therefore, students identified the necessary elements and determined the links between the elements, which requires an analysing process-one of HOTS.

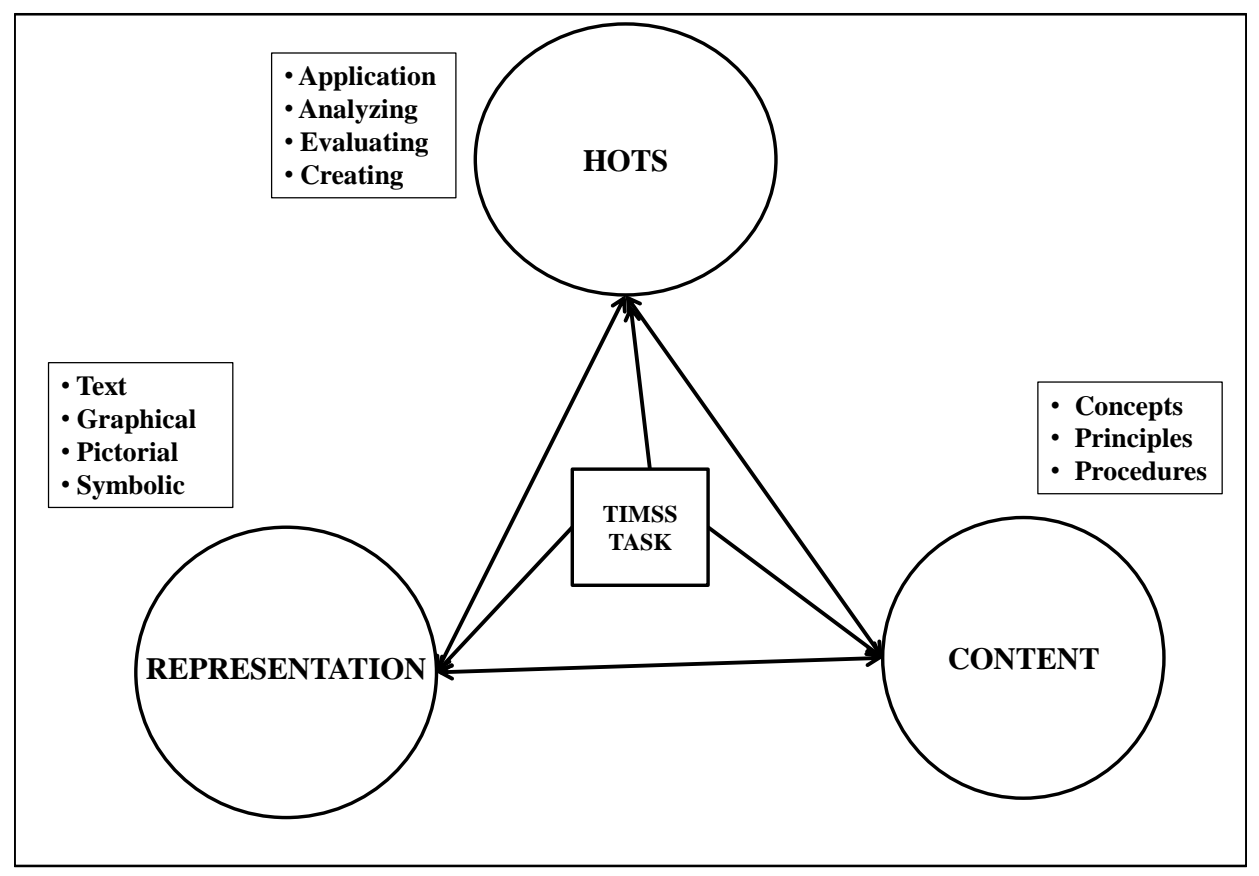

Figure 1: Relationship between HOTS and Task Variables

Content underpinning problems

Content underpinning TIMSS tasks includes concepts, principles or theorems and procedures. One of the most widely accepted ideas in mathematics education is that students should understand mathematical concepts (Hiebert \& Carpenter, 1992). In view of mathematics as a human activity, Godino (2013) emphasizes that mathematical concepts emerge from a person's acts for solving some problem fields. Consistent with this argument, Schoenfeld and Kilpatrick (2008) argued that, in order to understand the success or failure of a problem-solving attempt, one needs to know about the individual's mathematical conceptual knowledge base. Thus, students need to comprehend the conceptual knowledge embedded in the problems during solution processes.

It is very difficult to define what mathematical concepts are (Confrey, 1981). Some scholars provided a set of characteristics for concepts which contributes significantly to our understanding of the nature of mathematical concepts. For example, Confrey 
identified that a concept serves both as collectively disciplinary and reflecting individual's meaning of an entity. For instance, a concept of function has various disciplinary meaning such as "a relation is such that for any element in the domain there is exactly one element in the range" (Confrey, 1981, pg. 8). However, students may have private ideas of a function as an action, an operation, a rule, a relationship or a graph.

In addition, Hiebert and Carpenter (1992) illustrated mathematical concepts by relating them to conceptual knowledge which refers to knowledge of the underlying structure of mathematics and is characterised as knowledge that is rich in relationships (). It can also be thought as a connected web of knowledge, a network in which students are able to apply and link mathematical relationships to a variety of problems. For example, length, width, breadth, parameter and area are concepts in Geometric Measurement which are connected to each other.

Equally important are principles or theorems underlying a particular concept. For example, there are several principles of algebraic equations such as distributivity and associativity principles. Students use a variety of principles and procedures to determine which transformations of algebraic equations are appropriate. However, some students draw on distorted versions of these principles, such as the use of incorrect version of the distributive law: $\mathrm{a}+(b \times c)=(a+b) \times(a+c)$, instead of $a(b+c)=(a \times b)+(a \times c)$. Thus, both mathematical concepts and principles need to be comprehended in mathematical problem solving (Rittle-Johnson \& Schneider, 2012; Schoenfeld, 2013).

The solution of TIMSS tasks also requires the activation of procedural knowledge. Procedural knowledge consists of algorithms, or rules, for completing mathematical tasks (Hiebert \& Carpenter, 1992; Rittle-Johnson \& Schneider, 2012). It refers to stepby-step instructions that define precisely how to complete mathematical tasks or exercises in a predetermined linear sequence. For example, the steps involved in solving simultaneous linear equation are considered to be procedural in nature. In this instance, to solve the simultaneous linear equations, procedural skills such as simplifying the two equations, symbols manipulation, and procedures for developing equations with one unknown need to be applied. In other words, procedural knowledge can be described as knowing how to execute a particular task or activity which requires a certain sequence of actions.

\section{Representation of problems}

The notion of representation and its various types as the key construct of a unified psychological model of mathematical learning and problem solving is presented by Goldin (2008). In this article, we use the term Representation as the noting external representation which includes symbols, diagrams, and figures, amongst others. They enable us to observe that a student understand a given mathematical problem. These representations such as diagrams, tables, graphs as well as the conventional symbols used in mathematics can indicate the transformation of knowledge (internal representation). The duality internal/external representation is a key conception for Goldin. The term internal representation refers to the possible mental configurations of 
the solvers, comprising students' personal symbolization and assignments of meaning to mathematical notations. Under this category, Goldin (2008) also includes students' natural language, their visual imagery and spatial representation, and their affect in relation to mathematics.

In contrast, the external representation illustrates the "physically embodied, observable configurations such as words, graphs, pictures, equations, or computer micro-worlds" (Goldin \& Kaput, 1996, p. 400). An external representation is considered as a sign or configuration of signs, characters or objects that can stand for something else (to symbolise, code, provide an image of, or represent). The represented object can vary according to the context or the use of the representation. A Cartesian graph, for example, can represent a function or the solution to a set of algebraic equation. As an example, we consider a graph drawn in Cartesian coordinates by a student to represent the equation $y-2 x+3=0$ (external representation). The particular graph occurs within a system of coordinate representation, based on specific rules and conventions, which must be understood before the representational act can take place (internal representation).

Once a problem is represented, the students can use a number of strategies to achieve the problem goals. A review of literature shows that a number of such strategies could be used including trying a simple case, trial and improvement, drawing diagrams, identifying patterns, making a table, chart or systematic list, simulation, using analogies, working backwards, logical reasoning, and using algebra (CDC, 2011, Schoenfeld, 1985).

Students' acquire one or more the above range of strategies through their own problem solving experience as well as experiences from their peers. In addition, they can also learn the strategies through exploration and studying worked examples in textbooks. However, mastering of strategies may not guarantee success in problem solving because not all heuristics can be used to solve a particular problem (Schoenfeld, 1985; 2013; Tricot \& Sweller, 2013). Students need to develop a level of flexibility in making decisions about when to use a strategy and these decisions are based on their HOTS (Brookhart, 2010; Collins, 2014). While strategies are necessary, they can be activated only in the context of students' having developed mathematical concepts.

Furthermore, the strategies are only scaffolds that help to solve problems, and no strategies can replace the role of subject matter knowledge, concepts and skills in problem solving. In other words, strategies cannot offer in a vacuum. Thus, mathematics teachers need to understand the importance of teaching strategies explicitly so that students could develop an understanding of relationship between strategies and concepts during this problem solving attempt (Schoenfeld, 2013, Stein, Grover \& Henningsen, 1996).

Relationships between HOTS, Content and Representation: An example

We illustrate the links between HOTS, Content and Representation by considering a problem (Figure 2). In order to solve this problem, students need to convert the problem 
statement into a visual representation. This transformation requires students to identify the necessary elements and determine the links between these elements, a process that requires Analyzing - one of HOTS. Following the decision to translate the texts, students could construct a visual followed by symbolic representation (equation). This latter step of constructing involves Creating- another HOTS. Through the creation of the visual representation, students could focus on the mathematical content that underpins the problem including rectangular shape, semicircle, perimeter, area and integer. On completing the solution, students could also engage in activity that examine the reasonableness of the values of $x$ and $y-$ Evaluating (HOTS). The next step could involve the use of a strategy where the students solve the equation by working from the known to the unknown. Figure 3 illustrates the steps involved in solving the task.

Given $\mathrm{ABCD}$ is a piece of rectangular paper with an area of $28 \mathrm{~cm}^{2}$, a width of $7 x \mathrm{~cm}$ and a length of $y \mathrm{~cm}$. AEB is a semicircle-shaped cut from the paper. The remaining perimeter of the paper is $26 \mathrm{~cm}$. Find the integer values of $x$ and $y$ (Use $\pi=\frac{22}{7}$ ).

Figure 2: Mathematical Problem Task

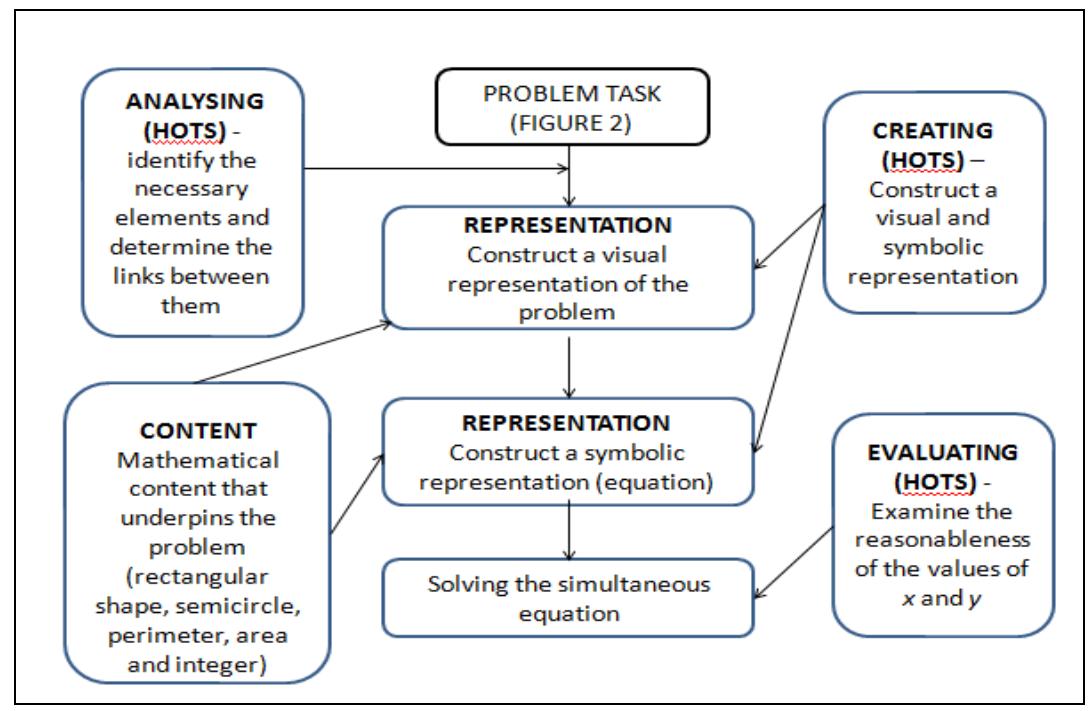

Figure 3: Steps in Solving Mathematical Problem Task in Figure 2

The process of setting up an equation or the generation of other equations involves translation from language to symbols. Collectively, these activities involve Analyzing and Evaluating such as detecting the appropriateness of a procedure for the given problem, activities that are formed parts of HOTS. In summary, mathematical problem solving requires algorithmic and non-algorithmic thinking by accessing relevant Content knowledge. This knowledge drives Representations, activation of strategies and HOTS, 
all of which work in tandem. In this interplay, it is important to recognise that all the three constructs (HOTS, Content, Representation) are interwoven and interdependent on each other.

\section{Analysis of Relationships between HOTS, Content and Representation: TIMSS Tasks}

\section{Example 1 (TIMSS 2011)}

As indicated in Figure 3, this task involves the establishment of inequalities (Content) and the identification of a strategy which could enable the students to determine the weight of one metal block. By critically Analyzing (HOTS) this problem, students need to transform the visual comparison of the weights into alternative Representations involving inequalities. Thus, the process of setting up these inequalities involves translation from visual to symbolic (inequality). While the Representation in the form of inequality is an important strategy, the building of this Representation involves integration of number of relevant information - Creating which is HOTS.

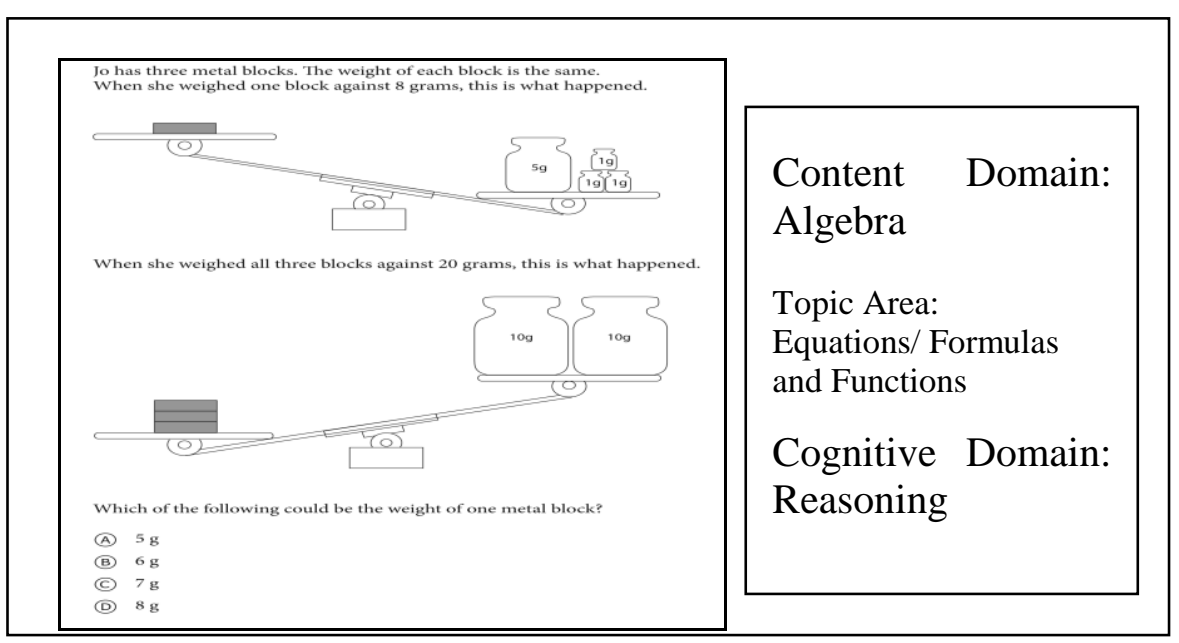

Figure 3: Example 1 of TIMSS 2011 Task

Students had to create two inequalities that are consistent with the two conditions of weight comparisons. Following this, they have to Evaluate (HOTS) which values for the weight of one metal block that will satisfy the condition of the inequalities. At this point, a guess-and-check strategy may be appropriate in producing a rapid solution. In applying the guess-and-check heuristics, students will iterate the process of substituting $5,6,7$, and 8 into the inequalities until the available solution is found. The solution also can be found by solving the inequalities algebraically to find the weight of one metal block. Both strategies involve Applying (HOTS) that focus on the students' ability to apply knowledge and concept to understand the question. In sum, throughout the solution process students have used cognitive processes of varying levels of complexity 
that are directly related to HOTS - Applying, Analyzing, Evaluating and Creating. Figure 4 illustrates the steps involved in solving example 1 of TIMSS task.

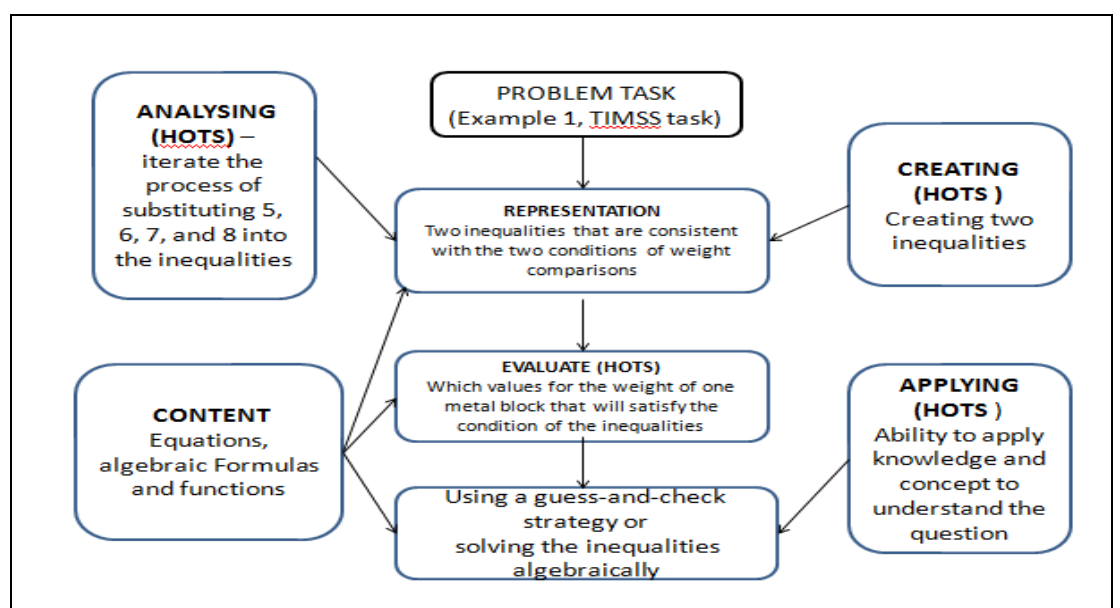

Figure 4: Steps Involved in Solving Example 1 of TIMSS Task.

Example 2 (TIMSS 2011)

Figure 5 is an example of a TIMSS problem that draws on concept based within the domain of Geometry and Measurement. Concepts such as solid geometry (cuboids), volume of a rectangular box, and volume of a book are crucial in solving this problem.

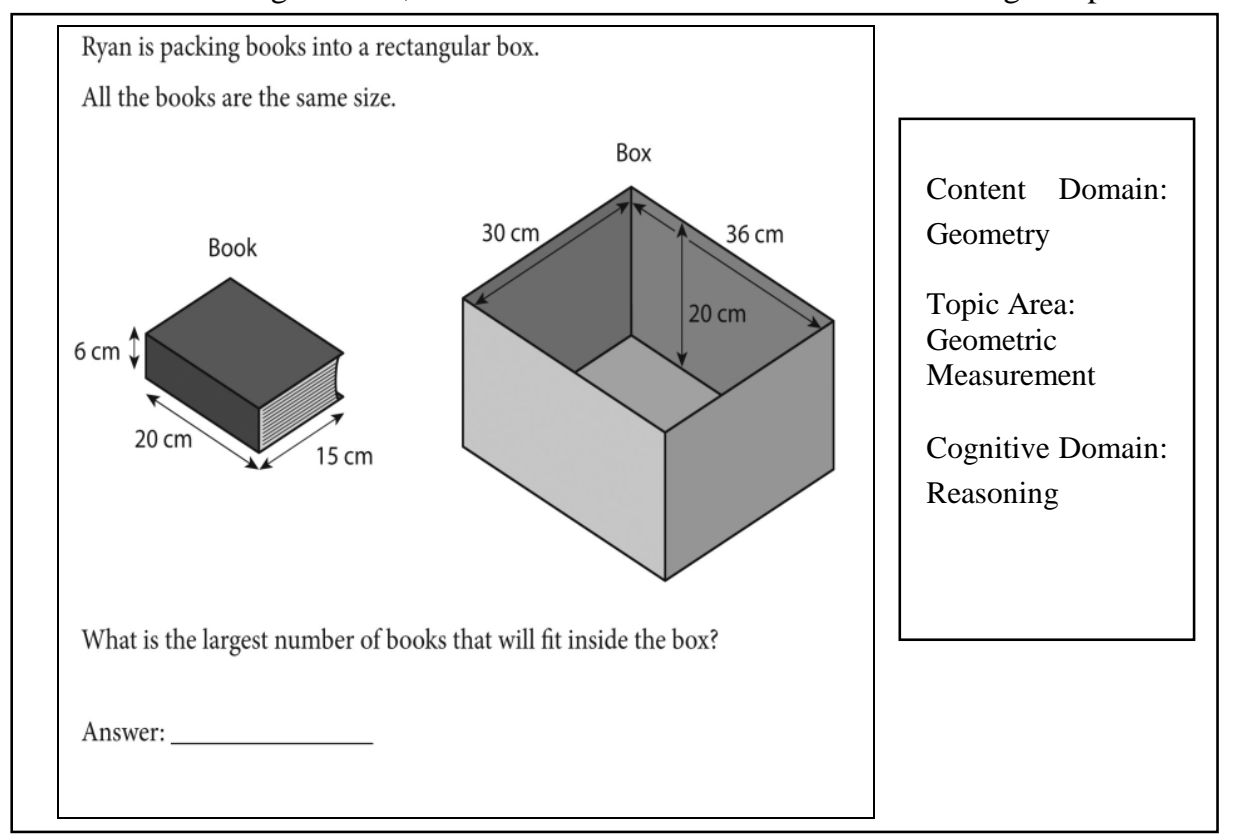

Figure 5: Example 2 of TIMSS 2011 Task 
In order to find the solution, students could begin by Evaluating [HOTS] the position of the book which will fit inside the box; whether the books should be organized in vertical or horizontal position to fill the larger box. This process will require students to orient the books in different directions (Figure 6). The orientation involves the construction of Books Orientation Diagram [BOD]. During the construction of the BOD students can be expected to comment the arrangement of the book vertically as the width of the box and book is $30 \mathrm{~cm}$ and $15 \mathrm{~cm}$, respectively. The thickness of the book is $6 \mathrm{~cm}$, and its' length is $20 \mathrm{~cm}$, while the length and height of the rectangular box is $36 \mathrm{~cm}$ and $20 \mathrm{~cm}$, respectively. Thus, the books can be arranged as indicated in Figure 4 so that and all the books fit inside the box. The arrangement and re-arrangement of books call for Analyzing and Creating - HOTS.

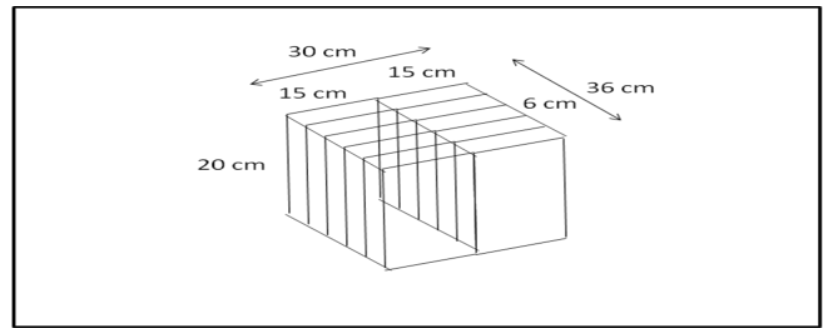

Figure 6: Systematic Arrangement of Books Orientation Diagram

Another possible way to analyze the problem is with a view to create an alternative Representation. In this representation, students could ask the following question: Suppose I have a solid rectangular object of volume $\left(\begin{array}{l}6 \\ x\end{array} 20 \times 15\right) \mathrm{cm}^{3}$, how many rectangular objects can be fitted into a larger rectangular box of volume $(20 \times 36 \times 30)$ $\mathrm{cm}^{3}$ ? This strategy of questioning oneself could assist the students to focus on the relationship between the smaller as part of the larger object. By using such a questioning strategy, the students could simplify the problem in terms of relationships. This simplified problem could be solved by drawing a 2-dimensional block (Figure 7). The solution can now be obtained through a process of division to determine the number of blocks that can be fitted into the larger box. We argue that the self-questioning strategy involves Evaluating and the simplification of the problem involves Creating, both highlighting activation of HOTS.

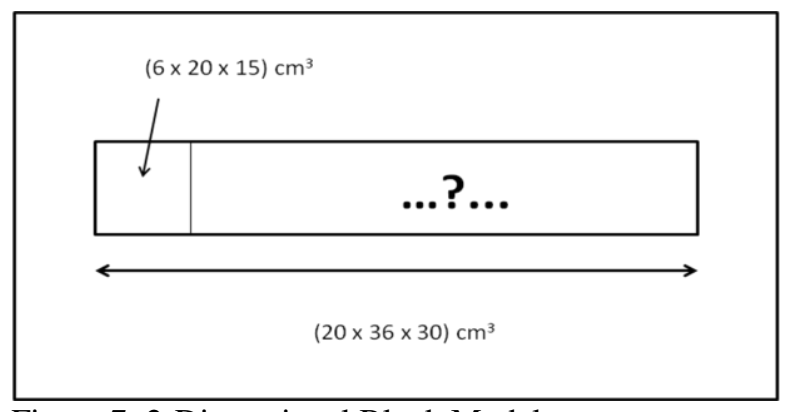

Figure 7: 2-Dimensional Block Model 


\section{FINDINGS}

This study was conducted to demonstrate how HOTS are crucial for students to move from one phase to another phase by activating relevant Content and applying this information during the construction of rich and powerful Representation. However, teachers play a critical role in foregrounding and integrating HOTS, Content and Representation in the above problem contexts. Our analyses shows that it is required to support teachers in understanding the above relationship in the context of non-routine problems such as those from TIMSS assessment.

The conceptual framework provided in Figure 1 explicates the links between HOTS, Content and Representation and provides a useful guide for classroom practice. In order for teachers to orcherstrate these three dimensions, they need to undertake the critical analyses of the mathematical tasks in question. Teacher education and professional learning programs could also target to build these relationships. Mathematics teachers need guidance in lesson planning that articulate a clear understanding of what constitute HOTS instruction, and how to implement them in regular classroom. The results of our tasks analyses and HOTS provides an important starting point for designing future professional development programs for not only Malaysian mathematics teachers but also teahers in general in better understanding and adapting HOTS into their secondary mathematics instruction.

\section{CONCLUSION}

In this paper, we have presented an analysis of TIMSS tasks that can be utilised by matematics teachers to understand the role of HOTS better in empowering students move from lower levels to higher levels of cognitive funtioning in the context of problem tasks that appear in TIMSS. We have attempted to make explicit the role of HOTS in helping students during the solution of problems that appear in TIMSS and other high-stakes assessment programs. In so doing, we have built a conceptual framework which relate the three key constructs: HOTS, Content and Representation.

Through a critical analysis of selected TIMSS tasks, we have showed how HOTS could play a significant role in mathematical understanding and problem solving. This conceptual framework constitutes a significant advancement in connecting literature on HOTS and in solution of problems that appear in TIMSS. In order to help teachers develop specific activities to support the students, future studies could examine the validity of this framework by emiprical means.

\section{REFERENCES}

Anderson, L. \& Krathwohl, D. A. (2001). Taxonomy for Learning, Teaching and Assessing: A Revision of Bloom's Taxonomy of Educational Objectives. New York: Longman. 
Brookhart, S. (2010), How to Assess Higher Order Thinking Skills in Your Classroom, ASCD, Available online http://www.ascd.org/Publications/Books/Overview/How-toAssess-Higher-Order-Thinking-Skills-in-Your-Classroom.aspx.

Collins, R. (2014). Skills for the 21st Century: teaching higher-order thinking. Curriculum and Leadership Journal. 12(4). Available online http://www.curriculum.edu.au/leader/teaching_higher_order_thinking,37431.html?issueID=12910.

Confrey, J. (1981). Concepts, processes and mathematics instruction. For the Learning of Mathematics 2: 8-12.

Curriculum Development Centre (2011). Kurikulum Bersepadu Sekolah Menengah, Spesifikasi Kurikulum Matematik Tingkatan 1, Putrajaya: Bahagian Pembangunan Kurikulum, Kementerian Pelajaran Malaysia. Available online: http://www.gov.moe.my.

Curriculum Development Centre (2013). Kemahiran Berfikir Aras Tinggi dalam Sains dan Matematik (Higher Order Thinking in Sciences and Mathematics (HOTsSM). Available online: http://www.gov.moe.my.

Ewing, J. C., Foster, D. D. \& Whittington, M. S. (2011). Explaining student cognition during class sessions in the context Piaget's theory of cognitive development. North American Colleges and Teachers of Agriculture Journal 55(1): 68-75.

Foy, P., Arora, A. \& Stanco, G. M. (2013). Timss 2011 User Guide for the International Database Released Items Mathematics - Eight Grade. Chestnut Hill, MA: TIMSS \& PIRLS International Study Center, Lynch School of Education, Boston College.

Goldin. G. A. (2008). Perspectives on representation in mathematical learning and problem solving. In L. D. English (Ed.) Handbook of International Research in Mathematics Education (pp. 176- 201), New York: Routledge.

Goldin, G. A. \& Kaput, J. J. (1996). A joint perspective on the idea of representation in learning and doing mathematics. In L.P. Steffe, P. Nesher, P. Cobb, G.A. Goldin, \& B. Greer (Eds.), Theories of mathematical learning (pp. 397-430), Hillsdale, NJ: Erlbaum.

Godino, J. D. (2013). Mathematical concepts, their meanings, and understanding. In L. Puig y A. Gutierrez (Eds.), Proceedings of XX Conference of the International Group for the Psychology of Mathematics Education, (v.2, pp. 417-425), Valencia: Universidad de Valencia.

Harpster, D. L. (1999). A study of possible factors that influence the construction of teacher-made problems that assess higher-order thinking skills. Unpublished Doctoral Dissertation. Montana, USA: Montana State University-Bozeman.

Hiebert, J. \& Carpenter, T. (1992). Learning and teaching with understanding. In D. A. Grouws (Ed.), Handbook of research on mathematics teaching and learning (pp. 6597), New York: Macmillan.

Hinde, E. R. \& Perry, N. (2007). Elementary teachers' application of Jean Piaget's theories of cognitive development during social studies curriculum debates in Arizona. The Elementary School Journal 108(1): 63-79. 
Marshall, J. C., \& Horton, R. M. (2011). The relationship of teacher facilitated inquirybased instruction to student higher-order thinking. School Science and Mathematics 111(3): 93-101.

Ministry of Education. (2011). KBSM Spesifikasi Kurikulum, Matematik Tingkatan 4, Kualla Lumpur: Bahagian PembangunanKurikulum, Kementerian Pelajaran Malaysia.

Ministry of Education. (2013). Malaysia Education Blueprint 2013-2025 (Preschoool to Post-Secondary Education, Putrajaya, Malaysia: Kementerian Pendidikan Malaysia.

Mullis, I. V. S., Martin, M. O., Foy, P. \& Arora, A. (2012). TIMSS 2011 International results in mathematics. Chestnut Hill, MA: TIMSS \& PIRLS International Study Center, Lynch School of Education, Boston College. Retrieved $2^{\text {nd }}$ January 2013, from http://timssandpirls.bc.edu/timss2011/downloads/T11_IR_Mathematics_FullBook.pdf.

National Council of Teachers of Mathematics (1989). Curriculum and evaluation standards for school mathematics.Reston. VA: NCTM.

Rittle-Johnson, B. \& Schneider, M. (2012). Developing conceptual and procedural knowledge in mathematics. In R. Cohen Kadosh \& A. Dowker (Eds.), Oxford handbook of numerical cognition. Oxford, UK: Oxford University Press.

Santos-Trigo, L. \& Moreno-Armella, L. (2013). International perspectives on problem solving research in mathematics education, a special issue. The Mathematics Enthusiast 10(1\&2): 3-8.

Schoenfeld A. H. (1985). Mathematical problem solving. Orlando, FL: Academic Press.

Schoenfeld, A. H. (2013). Reflections on problem solving theory and practice. In L. Santos-Trigo \& L. Moreno-Armella, International Perspectives on Problem Solving Research in Mathematics Education, a special issue, The Mathematics Enthusiast 10(1\&2): 9-34.

Schoenfeld, A. H. \& Kilpatrick, J. (2008). Toward a theory of proficiency in teaching mathematics. In D.Tirosh \& T. Wood (Eds.), The International Handbook of Mathematics Teacher Education: Vol. 2. Tools and Processes in Mathematics Teacher Education, (pp. 321-354), Rotterdam, Netherlands: Sense Publishers.

Stein, M. K., Grover, B. W., \& Henningsen, M. (1996). Building Student Capacity for Mathematical Thinking and Reasoning: An Analysis of Mathematical Tasks Used in Reform Classrooms. American Educational Research Journal, 33(2), 455-488.

Tricot, A \& Sweller, J. (2013), 'Domain-Specific Knowledge and Why Teaching Generic Skills Does Not Work', Educational Psychology Review, 1- 9. Available online: http://dx.doi.org/10.1007/s10648-013-9243-1.

Walker, M. (2011). PISA 2009 Plus results performance of 15-years olds in reading, mathematics and science for 10 additional participants. Melbourne: Australia Council for Educational Research (ACER). Available online http://research.acer.edu.au/cgi/viewcontent.cgi?article=1000\&context=pisa. 


\section{Turkish Abstract \\ TIMMS Görevlerini İyileștirmede Üst Düzey Düşünme Becerileri, Fikir Belirtme ve Kavramlar Arasındaki Bağlantı}

TIMMS'de öğrencilerin performansları konusu yakın zamanlarda tartışmalarda öğretmenler ve politika yapıcılar tarafından matematik öğrenme çıktılarının kalitesi hakkında yer bulmaktadır. TIMMS trendleri bulguları Malezya'daki lise öğrencilerinin çoğunun istenen düzeyden daha az performans gösterdiklerini göstermektedir. Özelikle zihinsel olarak zorlayıcı olanlarda. Bu makalede seçilen TIMMS görevlerinin eleştirel bir analizi yapılmış ve bu tür görevlerde ilerleme kaydetmede Üst Düzey Düşünme Becerilerinin (ÜDDB) kullanımının öğrencileri nasıl daha iyi destekleyeceği gösterilmiştir. Bunu yaparken TIMMS görevlerinin analizleri sunulmuştur. Ayrıca bu tür görevleri yaparken öğrencilerin daha üzt düzey bilişsel becerilerinin kullanılmasını sağlayan ve öğretmenler tarafindan kullanılabilen ÜDDB'ler, fikir belirtmeler ve kavramlarla ilişkili görev modeli sunulmuştur. Bu analizler ve model Malezyalı matematik öğretmenlerinin sınıfta ÜDDB'nin tekrar kavramsallaştırlması ve uygulanması için gelecek mesleki gelişim programlarının tasarımında bir başlangıç noktası sağlayacaktır.

Anahtar Kelimeler: düşünme becerileri, problem çözme matematik, TIMMS görevleri, öğretmen, biliş düzeyi, fikir belirtme

\section{French Abstract \\ Le Lien entre Ordre Plus Haut Pensant Compétences, Représentation et Concepts dans Amélioration TIMSS Tâches}

Les performances des Étudiants dans TIMSS ont figuré fortement dans des discussions récentes et des débats de la qualité de résultats d'apprentissage mathématiques tant de professeurs que des décideurs. Les découvertes de tendances TIMSS ont montré que la plupart des lycéens en Malaisie continuent à fonctionner à moins que des niveaux satisfaisants. Particulièrement, dans les tâches qui sont cognitivement exigeantes. Dans cet article, nous présentons une analyse critique de Tâches TIMSS choisies et démontrons comment mieux soutenir des étudiants dans l'utilisation d'Ordre Plus haut Pensant des Compétences (HOTS) dans des progrès avec de telles tâches. Ainsi nous présentons les analyses de tâches TIMSS et un modèle de ces tâches qui relatent HOTS, la représentation et les concepts qui peuvent être utilisés par les professeurs comprennent mieux le rôle de HOTS dans l'autorisation du changement d'étudiants aux niveaux plus hauts de funtioning cognitif dans le contexte d'aborder TIMSS et des tâches de la même façon exigeantes. Nos analyses et modèle fournissent un point de départ important pour la conception de programmes de développement professionnels futurs pour des professeurs de mathématiques malais dans la reconceptualisation HOTS et la mise en oeuvre d'eux dans des salles de classe régulières.

Mots Clés: en pensant compétences, résolution de problèmes, mathématiques, Tâches TIMSS, professeur, niveau de connaissance, representation 
Arabic Abstract

TIMSS Tasks ارتباط بين مهارات التفكير العليا، التمثيل والمفاهيم في تعزيز

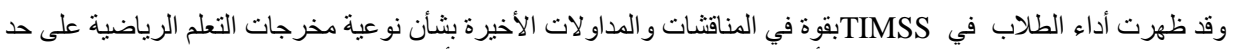

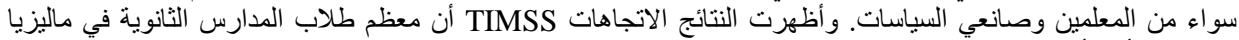

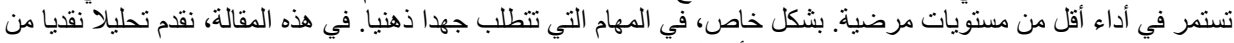

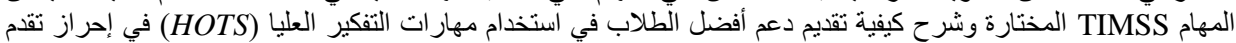

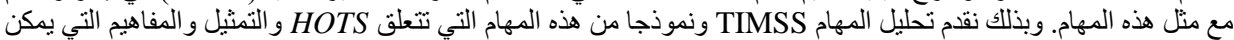
استخدامها من قبل المعلمين فهم أفضل لدور

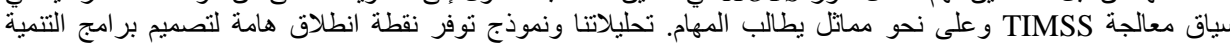
المهنية في المستقبل لمعلمي الرياضيات الماليزي في إعادة مخططاته HOTS وتنفيذها في الفصول الدراسية العية العادية. كلمات البحث: مهار ات التفكير وحل المشكلات، والرياضيات، TIMSS Tasks، المعلم، ومسنوى الإدر اكو والتمثيل.

\section{German Abstract \\ Die Verbindung zwischen höherer Ordnung Denken Fähigkeiten, Vertretung und Konzepte in der Verbesserung der TIMSS-Aufgaben}

In TIMSS Schüler Aufführungen wurden in den letzten Diskussionen und Debatten über die Qualität der mathematischen Lernergebnisse sowohl von den Lehrern und Politikern merkmalsreichen. Würdigung durch TIMSS Trends zeigten, dass die meisten High-SchoolStudenten in Malaysia weiterhin bei weniger als zufriedenstellendes Niveau zu erfüllen. Insbesondere bei Aufgaben, die kognitiv anspruchsvoll. In Fortschritte bei solchen Aufgaben In diesem Artikel stellen wir eine kritische Analyse der TIMSS-Aufgaben ausgewählt und zeigen, wie man besser die Schüler bei der Nutzung von Höherer Ordnung Denkfähigkeiten (HOD) unterstützen. Dabei stellen wir Analysen von TIMSS Aufgaben und ein Modell dieser Aufgaben, die HOD, Repräsentation und Konzepte beziehen, die von den Lehrern genutzt werden kann besser die Rolle des HOD verstehen bei der Stärkung Studenten zu höheren Ebenen der kognitiven funtioning im Rahmen verschieben TIMSS der Bekämpfung von und ähnlich anspruchsvolle Aufgaben. Unsere Analysen und Modell einen wichtigen Ausgangspunkt für die Gestaltung der künftigen Berufsentwicklungsprogramme für den Malaysian Mathematiklehrer in Rekonzeptualisierung HOD und sie in regelmäßigen Klassen implementieren.

Schlüsselwörter: denkfähigkeiten, problemlösung, mathematik, TIMSS aufgaben, lehrer, ebene der erkenntnis, repräsentation

\section{Malaysian Abstract \\ Hubungan antara Kemahiran Berfikir Aras Tinggi, Perwakilan dan Konsep dalam Meningkatkan Tugasan TIMSS}

Pencapaian pelajar dalam TIMSS telah dipaparkan dengan kukuh dalam perbincangan baru-baru ini dan perbahasan tentang kualiti hasil pembelajaran matematik antara guru dan pembuat dasar. Hasil trend TIMSS menunjukkan kebanyakan pelajar sekolah tinggi di Malaysia terus menunjukkan prestasi yang kurang daripada tahap yang memuaskan. Terutama, dalam tugas-tugas yang kognitif mencabar. Dalam artikel ini, kami membentangkan analisis kritikal bagi tugasan TIMSS dipilih dan menunjukkan bagaimana untuk menyokong pelajar dalam penggunaan Kemahiran Berfikir Aras Tinggi (HOTS) dalam membuat kemajuan yang lebih baik bagi setiap tugas. Dengan berbuat demikian kami membentangkan analisis tugasan TIMSS dan model 
tugasan ini yang berkaitan HOTS, perwakilan dan konsep yang boleh digunakan oleh guru-guru supaya lebih memahami peranan HOTS dalam memperkasakan pelajar supaya beralih kepada tahap yang lebih tinggi fungsi kognitif dalam konteks menangani TIMSS tugasan yang mencabar. Analisis dan model kami menyediakan titik permulaan yang penting untuk reka bentuk program pembangunan profesional masa depan untuk guru-guru matematik Malaysia konseptual HOTS dan melaksanakannya dalam kelas biasa.

Kata Kunci: kemahiran berfikir, penyelesaian masalah, matematik, Tugasan TIMSS, guru, tahap kognisi, perwakilan 